\title{
Assessing Marketing Literature: A Study of the Readings Assigned in Doctoral Seminars in Marketing
}

\section{Kathleen E. Joswick, Ronald J. Bauerly, and Don T. Johnson}

The researchers analyzed the assigned readings from the syllabi of doctoral marketing seminars from forty institutions to identify the format, age, and subjects of the materials assigned to and read by graduate students in the field. The overwhelming majority of the assigned readings were journal articles, but monographic material was still frequently used. A relatively small number of journal titles were used consistently across all the programs. There was a distinct lack of agreement on individual article or book selection among the programs. Current resources were favored, but seminal articles in both monographic and serial format were still included. Implications of the findings for libraries and for doctoral education are discussed.

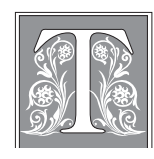

he discipline of marketing has been defining itself over the past century. Through shifting paradigms and expanding parameters, the field is developing into a dynamic, interdisciplinary area of study that combines practical, quantitative, and theoretical aspects. As with any emerging discipline, identifying and acquiring the resources relied on by its scholars is challenging for librarians. Nonetheless, librarians have the responsibility to anticipate and supply appropriate resources to researchers, teachers, and students in this evolving profession.

In order to improve the understanding of the use patterns of sources in marketing, this study investigated the assigned reading lists from doctoral-level mar- keting seminars. Readings required by marketing professors, the scholars whose vision defines and advances the identity of the discipline, profoundly impact the field. Likewise, they heavily influence the students in the doctoral classes - the future teachers and researchers who will formulate and disseminate marketing thought in both industry and classrooms. By analyzing the works assigned and read in doctoral seminars, the researchers documented the resources actually used by professors and students, both serious consumers of published marketing materials. These resources will be influential in shaping the knowledge base of the marketing discipline in the decades to come. The findings of this study will help librarians, university administra-

Kathleen E. Joswick is a Professor in University Libraries and Ronald J. Bauerly and Don T. Johnson are Professors in the Department of Marketing and Finance, all at Western Illinois University; e-mail: k-joswick@wiu.edu; mfrjb@wiu.edu; and DT-Johnson@wiu.edu, respectively. 
tors, and marketing professionals assess the use of existing literature and provide a prospectus for collection development in the future.

\section{Literature Review}

Earlier studies evaluating the comparative influence or use of resources in the field of marketing in general have been either subjective or objective. The primary subjective method used was the key informant survey. Key informant studies provide a useful appraisal of the perceived status of resources. (See Browne and Becker; Clark; Coe and Weinstock; Fry, Walters, and Scheuerman; Gordon and Heischmidt; Luke and Doke; and Theoharakis and Hirst. ${ }^{1-9}$ ) In one recent study of this kind, G. Tomas M. Hult, William T. Neese, and R. Edward Bashaw asked marketing faculty to rank the ten most important journals from a list of sixty-three marketing-related titles. ${ }^{10}$ Participants ranked Journal of Marketing as the most prestigious journal, followed by Journal of Marketing Research, Journal of Consumer Research, Journal of Retailing, and Journal of the Academy of Marketing Science.

Citation-based measures, typically using data from the Social Sciences Citation Index (SSCI), utilize a common objective method of determining journal influence. A number of studies have employed this approach. (See Chandy and Williams; Cote, Leong, and Cote; Leong; Pieters et al.; Zinkhan and Leigh; and Zinkhan, Roth, and Saxon. ${ }^{11-16}$ ) Hans Baumgartner and Rik Pieters gathered 1996-1997 SSCI citation data to measure the influence of forty-nine marketing and marketingrelated journals on the discipline and its subareas. ${ }^{17}$ They identified the same the top three journals as Hult, with the Journal of Marketing first in level of influence and the Journal of Marketing Research and the Journal of Consumer Research second and third, respectively.

Investigating the availability of journals in university libraries is another objective measure of journal importance. Frank R. Urbanic and J. Franklin Sailors looked at journal holdings in libraries and found that the six most commonly held marketing journals at doctoral-granting institutions were Journal of Marketing, Journal of Retailing, Journal of Advertising (all held by $100 \%$ of the libraries studied), Journal of Marketing Research (held by $97.4 \%$ of the libraries), Journal of Advertising Research and the Journal of Consumer Research (both held by $94.7 \%$ of the libraries). ${ }^{18}$ Michael J. Polansky, Gary Jones, and Megan J. Kearsley examined Australian library holdings of marketing journals. ${ }^{19}$ The Strategic Management Journal was the Australian libraries' most commonly held journal, followed by the Journal of Marketing Research, Journal of Advertising Research, and the Journal of Business. Interestingly, the California Management Review in fifth place and the Australian Journal of Marketing in sixth place appeared in libraries more often than the Journal of Marketing (seventh) or the Journal of Consumer Research (eighth).

Studying the readings assigned in doctoral seminars provides another objective method of measuring the influence of resources. Although no comprehensive doctoral marketing seminar study has been published to date, David L. Kurtz et al. reviewed syllabi from doctorallevel marketing theory seminars. ${ }^{20}$ The primary focus of the Kurtz study was the content and structure of theory courses, but the authors did find that twenty of the twenty-five most frequently assigned articles in the participating seminars came from the Journal of Marketing. Louis Capella and Ronald Taylor surveyed the instructors of marketing theory courses but did not gather any actual syllabi. ${ }^{21}$ They reported that three well-known marketing journals - Journal of Marketing, Journal of Marketing Research, and Journal of the Academy of Marketing Science - were the most frequently cited journals.

The work that most closely parallels the current study is "Journal Influence on the Design of Finance Doctoral Education," by Charles J. Corrado and Stephen P. Ferris. ${ }^{22}$ The authors collected 101 syllabi 
from 33 finance doctoral programs. From these syllabi, they created a database of 3,273 citations to finance, economics, and accounting journals. The Journal of Finance dominated their citation list with 36.1 percent of the citations, followed by the Journal of Financial Economics with 27.9 percent. The remaining fifteen journals were cited in fewer than 10 percent of the syllabi.

Each of these methods of measuring the comparative influence of marketing resources has limitations. Key informants' perceptions are subject to bias stemming from such things as the rater's familiarity with various resources, area of expertise, and perception of the status of the resources apart from their actual use. The rater also may be tempted to give greater consideration to those journals in which he or she has published articles, served on its editorial board, or was otherwise connected. ${ }^{23}$ Although citation index studies are commonly accepted as use studies, the citation indexes rank only journals - and a rather limited pool of journals at that. Library holdings studies record existing collection norms but do not necessarily reflect use. Each of these methods falls short of accurately mirroring the complete spectrum of resources used by marketing scholars.

The present study combines elements of both the citation and the key informant measures. Examining the references listed on syllabi from doctoral marketing seminars is certainly a citation analysis. However, the fact that the professors teaching the doctoral seminars select these references imparts an element of a key informant study. This methodology, not used before to examine marketing resources, analyzes all the sources that comprise doctoral seminar readings and therefore evaluates their use and relative influence on the discipline of marketing and related fields of inquiry.

\section{Methodology}

During the spring of 2001, the researchers sent letters to all of the 101 universi- ties that offer doctoral-level programs in marketing as identified by the AACS's Doctoral Programs in Business \& Management in the USA. ${ }^{24}$ They requested copies of the syllabi from current or recent doctoral seminars. Follow-up letters and e-mails were sent to nonresponding programs. As a result of these solicitations, the researchers received responses from forty-eight institutions. Five responders indicated that they no longer offered doctoral seminars in marketing; three sent incomplete or unusable information. In the end, the researchers studied 108 usable syllabi from 40 different institutions $(41.7 \%$ of the marketing programs). The participating institutions represent a cross section of marketing departments from highly ranked business schools in the United States and Canada. Half the samples' schools and slightly over half of all the citations studied came from graduate business schools that were ranked in the top fifty by the U.S. News $\mathcal{E}$ World Report in $2001 .{ }^{25}$ Based on the stated program requirements, the sample syllabi represent 68 percent of the required doctoral marketing seminars from the respective institutions.

The topics of the seminars fell into five broad categories: consumer behavior $(22$ seminars, or $20.4 \%$ of the total number of courses studied), quantitative marketing models (15 seminars, or $13.9 \%$ ), research methods (17 seminars, or $15.7 \%$ ), marketing strategy (20 seminars, or $18.5 \%$ ), and marketing theory (16 seminars, or $14.8 \%$ ). Other seminars were marketing channels (5 seminars, or $4.6 \%$ ), international marketing (4 seminars, or $3.7 \%$ ), multivariate statistics ( 3 seminars, or $2.8 \%$ ), and six others (5.6\%).

Syllabi from seminars offered by the same professor at the same universities in consecutive terms or years were counted as a single syllabus. Table 1 lists the universities supplying syllabi to the study, the number of syllabi each institution provided, and the number of citations that were studied from these syllabi. 


\begin{tabular}{|c|c|c|c|c|c|}
\hline \multicolumn{6}{|c|}{$\begin{array}{c}\text { TABLE } 1 \\
\text { University Sources of Syllabi and Citations }\end{array}$} \\
\hline School & Syllabi & Citations & School & Syllabi & Citations \\
\hline Boston U & 5 & 152 & U of British Columbia & 2 & 122 \\
\hline Cleveland State U & 1 & 92 & $\begin{array}{l}\text { U of Calif. at Los } \\
\text { Angeles }\end{array}$ & 3 & 174 \\
\hline Cornell U & 2 & 111 & U of Calif. at Berkeley & 3 & 239 \\
\hline Duke U & 2 & 215 & U of Chicago & 1 & 12 \\
\hline Florida State U & 3 & 175 & $\mathrm{U}$ of Illinois & 2 & 202 \\
\hline Georgia State U & 5 & 150 & U of Illinois-Chicago & 2 & 127 \\
\hline Indiana U & 2 & 98 & U of Kentucky & 4 & 264 \\
\hline London Business & 1 & 61 & U of Maryland & 2 & 89 \\
\hline Louisiana State U & 1 & 153 & $\mathrm{U}$ of Michigan & 1 & 50 \\
\hline New Mexico State & 2 & 176 & U of Minnesota & 5 & 369 \\
\hline New York U & 2 & 186 & U of Missouri & 2 & 222 \\
\hline Oklahoma State U & 1 & 148 & $\mathrm{U}$ of North Carolina & 2 & 96 \\
\hline Pennsylvania State & 3 & 147 & $\begin{array}{l}\text { U Pennsylvania } \\
\text { (Wharton) }\end{array}$ & 4 & 297 \\
\hline Queens U & 4 & 275 & U of Southern California & 5 & 494 \\
\hline Southern Illinois U & 5 & 322 & U of South Florida & 3 & 323 \\
\hline Stanford U & 3 & 113 & U of Texas-Austin & 4 & 254 \\
\hline Texas A\&M U & 1 & 71 & $\mathrm{U}$ of Toronto & 4 & 209 \\
\hline Texas Tech U & 3 & 300 & U of Utah & 1 & 46 \\
\hline U of Arizona & 1 & 270 & $\mathrm{U}$ of Washington & 4 & 177 \\
\hline U of Arkansas & 4 & 150 & York U & 3 & 123 \\
\hline
\end{tabular}

The researchers investigated incomplete or unclear citations in bibliographic and Web-based databases to verify and/or complete as many citations as possible. They eventually identified approximately 99 percent of the cited references. To avoid the undue influence that could result from one article being cited in multiple reading lists from one program, duplicate journal article citations from the same institution were removed. However, citations to entire books were counted each time they were referenced. Multiple references to different articles from the same book of collected readings within a syllabus were counted as only one citation to the book. The resulting 7,254 references to required or recommended sources cited in the syl- labi were entered into a spreadsheet and analyzed.

\section{Format}

Over 86 percent of the recommended readings were journal articles $-6,294$. Formats other than journal articles represented only slightly more than 13 percent of the citations. The syllabi included 832 citations to books: $578(7.9 \%)$ citations to entire books and $254(3.5 \%)$ citations to edited collections of readings, for a total of 11.45 percent of the total citations. References to working papers, frequently authored by the professor conducting the seminar, numbered 97, or 1.34 percent. Conference proceedings or presentations represented another 0.25 percent. An insignificant number of cita- 
tions were made to articles published in newspapers or popular magazines, and videos, short stories, or news transcripts. One Web site was cited.

Obviously, journal articles heavily influence doctoral-level studies in marketing. Scholarly and professional journals in marketing, management, and human behavior are the dominant format of the literature for the marketing discipline as a whole. Their importance for collection development in the field cannot be overstated.

Citations to books and articles or chapters from anthologies comprised over 11 percent of the readings. Although the principal method of communication among marketing scholars has shifted from books to journal articles over the decades of the discipline's development, books continue to play an important part in the education of marketing scholars. Journal collections and electronic full-text databases alone cannot provide the entire range of materials required in the discipline. Librarians must vigorously defend materials budgets to ensure that they have the financial resources to continue to collect monographic material in marketing and its related areas.

The only other resource format that was significantly cited in the seminars was working papers. Of the ninety-seven citations identified as unpublished worksin-progress, the professor of the seminar authored thirty-eight $(39.17 \%)$. Although it is difficult to envision a way in which librarians could predict the need for and collect this type of document, it is remarkable to note that unpublished papers were cited more than newspapers, magazines, conference proceedings, or Web sites combined. Tracking the research interests of the institution's marketing professors and producing bibliographies or collections of the works-in-progress of local researchers would be a way that librarians could enrich their local collections.

\section{The Cited Journals}

The syllabi included references to articles from 248 research journals. Fifty-seven journals were cited ten or more times. These frequently cited journals represent 22.9 percent of all the cited journals, but they accounted for 93.4 percent of the article citations. At the other end of the spectrum, one hundred journals (40.3\% of the total number of journal titles) were cited only once. One hundred seventy-three $(69.8 \%)$ of the journals were mentioned five times or fewer. The least frequently cited journals account for only 304 , or 4.8 percent, of the total number of article citations. Once again, research confirms the fact that a small number of journals account for the majority of the use. The leading journals with the number and percentage of citations are listed in table 2. Because these journals so dominate the seminars' reading lists, libraries supporting programs in marketing will recognize the significance of these fifty-seven titles.

The most frequently cited journals were the core journals in marketing. Journal of Marketing, Journal of Consumer Research, Journal of Marketing Research, Marketing Science, and Journal of the Academy of Marketing Science accounted for $4,194(66.63 \%)$ of all the article citations. Notable in these results, however, is the portion of citations that came from journals that were not considered in prior research. Journal of Marketing, Journal of Consumer Research, and Journal of Market Research occupied the first through third rankings in the current study as well as the key informant survey by G. Tomas M. Hult, William T. Neese, and R. Edward Bashaw and the citation analysis study by Baumgartner and Pieters. ${ }^{26,27}$ Marketing Science and the Journal of the Academy of Marketing Science were also highly ranked in all three studies. After these core journals, however, the other high-ranking journals diverge strongly. For example, the Journal of Retailing was twentieth in the current study, but fourth and fifth on the Hult surveys and ninth on the Baumgartner and Pieter list. Harvard Business Review was tenth in this ranking, but seventh on the Hult surveys and 


\begin{tabular}{|c|c|c|c|}
\hline \multicolumn{4}{|c|}{$\begin{array}{c}\text { TABLE } 2 \\
\text { Journals Cited Ten or More Times }\end{array}$} \\
\hline Rank & Title of Journal & $\begin{array}{c}\text { Number } \\
\text { of Citations }\end{array}$ & $\begin{array}{c}\text { \% of } \\
\text { Citations }\end{array}$ \\
\hline 1 & Journal of Marketing & 1,434 & 22.8 \\
\hline 2 & Journal of Consumer Research & 1,217 & 19.3 \\
\hline 3 & Journal of Marketing Research & 853 & 13.6 \\
\hline 4 & Marketing Science & 476 & 7.6 \\
\hline 5 & Journal of the Academy of Marketing Science & 206 & 3.3 \\
\hline 6 & Management Science & 141 & 2.4 \\
\hline 7 & Journal of Personality and Social Psychology & 111 & 1.8 \\
\hline 8 & Psychological Bulletin & 96 & 1.5 \\
\hline 9 & Strategic Management Journal & 92 & 1.5 \\
\hline 10 & Harvard Business Review & 80 & 1.3 \\
\hline 11 & Psychological Review & 71 & 1.1 \\
\hline 12 & American Psychologist & 67 & 1.1 \\
\hline 13 & Journal of International Business Studies & 64 & 1.0 \\
\hline 14 & Academy of Management Review & 54 & 0.9 \\
\hline 15 & International Journal of Research in Marketing & 43 & 0.7 \\
\hline 16 & Annual Review of Psychology & 37 & 0.6 \\
\hline 17 & Administrative Science Quarterly & 36 & 0.6 \\
\hline 18 & Journal of Business & 33 & 0.5 \\
\hline 18 & Rand Journal of Economics & 33 & 0.5 \\
\hline 18 & Structural Equation Modeling & 33 & 0.5 \\
\hline 21 & American Economic Review & 32 & 0.5 \\
\hline 21 & Journal of Retailing & 32 & 0.5 \\
\hline 23 & Advances in Consumer Research & 30 & 0.5 \\
\hline 24 & Marketing Letters & 29 & 0.5 \\
\hline 25 & Journal of Services Marketing & 28 & 0.4 \\
\hline 25 & $\begin{array}{l}\text { Organizational Behavior and Human } \\
\text { Decision Processes }\end{array}$ & 28 & 0.4 \\
\hline 27 & Academy of Management Journal & 27 & 0.4 \\
\hline 27 & Journal of Consumer Psychology & 27 & 0.4 \\
\hline 29 & Journal of Business Research & 26 & 0.4 \\
\hline 30 & American Marketing Association Proceedings & 23 & 0.4 \\
\hline 30 & Journal of Political Economy & 23 & 0.4 \\
\hline 30 & Quarterly Journal of Economics & 23 & 0.4 \\
\hline 33 & Journal of Macromarketing & 20 & 0.3 \\
\hline 34 & Econometrica & 19 & 0.3 \\
\hline 34 & Journal of Advertising Research & 19 & 0.3 \\
\hline
\end{tabular}




\begin{tabular}{|c|c|c|c|}
\hline \multicolumn{4}{|c|}{$\begin{array}{c}\text { TABLE } 2 \\
\text { Journals Cited Ten or More Times }\end{array}$} \\
\hline Rank & Title of Journal & $\begin{array}{c}\text { Number } \\
\text { of Citations }\end{array}$ & $\begin{array}{c}\text { \% of } \\
\text { Citations }\end{array}$ \\
\hline 36 & Journal of Service Research & 18 & 0.3 \\
\hline 37 & American Journal of Sociology & 16 & 0.3 \\
\hline 37 & Journal of Economic Perspectives & 16 & 0.3 \\
\hline 37 & Journal of Public Policy and Marketing & 16 & 0.3 \\
\hline 37 & Public Opinion Quarterly & 16 & 0.3 \\
\hline 41 & Journal of Applied Psychology & 14 & 0.2 \\
\hline 41 & Psychological Science & 14 & 0.2 \\
\hline 41 & Sloan Management Review & 14 & 0.2 \\
\hline 44 & Business Horizons & 13 & 0.2 \\
\hline 44 & Educational and Psychological Measurement & 13 & 0.2 \\
\hline 44 & $\begin{array}{l}\text { Journal of Experimental Psychology: Learning, } \\
\text { Memory, \& Cognition }\end{array}$ & 13 & 0.2 \\
\hline 44 & Science & 13 & 0.2 \\
\hline 48 & Journal of Management & 12 & 0.2 \\
\hline 48 & Organizational Science & 12 & 0.2 \\
\hline 48 & Personality and Social Psychology Bulletin & 12 & 0.2 \\
\hline 48 & Philosophy of the Social Sciences & 12 & 0.2 \\
\hline 48 & Psychological Methods & 12 & 0.2 \\
\hline 48 & Psychometrika & 12 & 0.2 \\
\hline 54 & Journal of Business Logistics & 11 & 0.2 \\
\hline 55 & Decision Sciences & 10 & 0.2 \\
\hline 55 & Multivariate Behavioral Research & 10 & 0.2 \\
\hline 55 & Operations Research & 10 & 0.2 \\
\hline
\end{tabular}

fourth on the Baumgartener citation list. Journals with reputations for publishing research that is more empirical and practical, such as Journal of Advertising, Journal of Advertising Research, and Journal of Public Policy and Marketing, were ranked as high as ninth on the survey and citation lists but were not even in the top twenty-five journals in this study. Nearly one-sixth $(16.5 \%)$ of the journals cited in this study were not examined in two extensive key informant and citation analyses studies of journal importance. The fifty-seven most frequently cited journals in this study include thirty-three journals not even included in the two earlier articles.

In previous key informant surveys, faculty at universities with doctoral programs in marketing have indicated they believe that "practical" journals such as Journal of Advertising, Journal of Advertising Research, Strategic Management Journal, and Harvard Business Review are important and effective at transmitting information to the field. Yet, they infrequently assign readings from these journals in their doctoral seminars. In actual practice, faculty rely heavily on the 
Journal of Marketing, Journal of Consumer Research, and Journal of Marketing Research (55.7\% of all citations), less extensively on Marketing Science and the Journal of the Academy of Marketing Society (11.0\%, combined), and then fill in with psychology and management literature. Of the 6,294 journal citations in the syllabi, the Journal of Advertising was cited only three times and the Journal of Personal Selling and Sales Management once. Articles published in any journal other than the top five marketing journals are much less likely to influence the education of new marketing doctorates.

Identifying the call numbers suggested by the Library of Congress for the journals enabled the researchers to categorize them into the broad subject areas. Suggested call numbers were located for 243 of the 248 journals. Obviously, marketing journals were most commonly used; 21.4 percent (53) of all the journals were classified in HF. Journals in psychology and/or psychiatry (BF and RC classifications) comprised the second largest group of journals with 43 , or 17.7 percent. Management titles (HD, HE) were a close third with 38, or 15.6 percent. Economics (HB,
$\mathrm{HC}, \mathrm{HG}$ ) and the combined disciplines of sociology and anthropology (G and HM$\mathrm{HV}$ ) made up the next largest groups. The varied subjects of the cited journals illustrate how heavily the discipline of marketing is influenced by publications from journals in related, yet diverse, fields. (See figure 1.)

\section{The Cited Articles}

Despite the fact that the syllabi cited journals from a wide array of disciplines, looking at the numbers of articles cited from the journals rather than the numbers of journal titles cited revealed an overwhelming predominance of articles from marketing journals (over 75\%). The fifty-two journals identified as marketing titles constitute the primary resources for doctoral studies in marketing. Not surprisingly, the articles cited from other disciplines are dwarfed when compared to those from the field of marketing. (See figure 2.)

Although this study established a list of frequently cited journal titles, there was considerable scatter in the actual articles that appeared on the reading lists. One article was cited fourteen times, and two

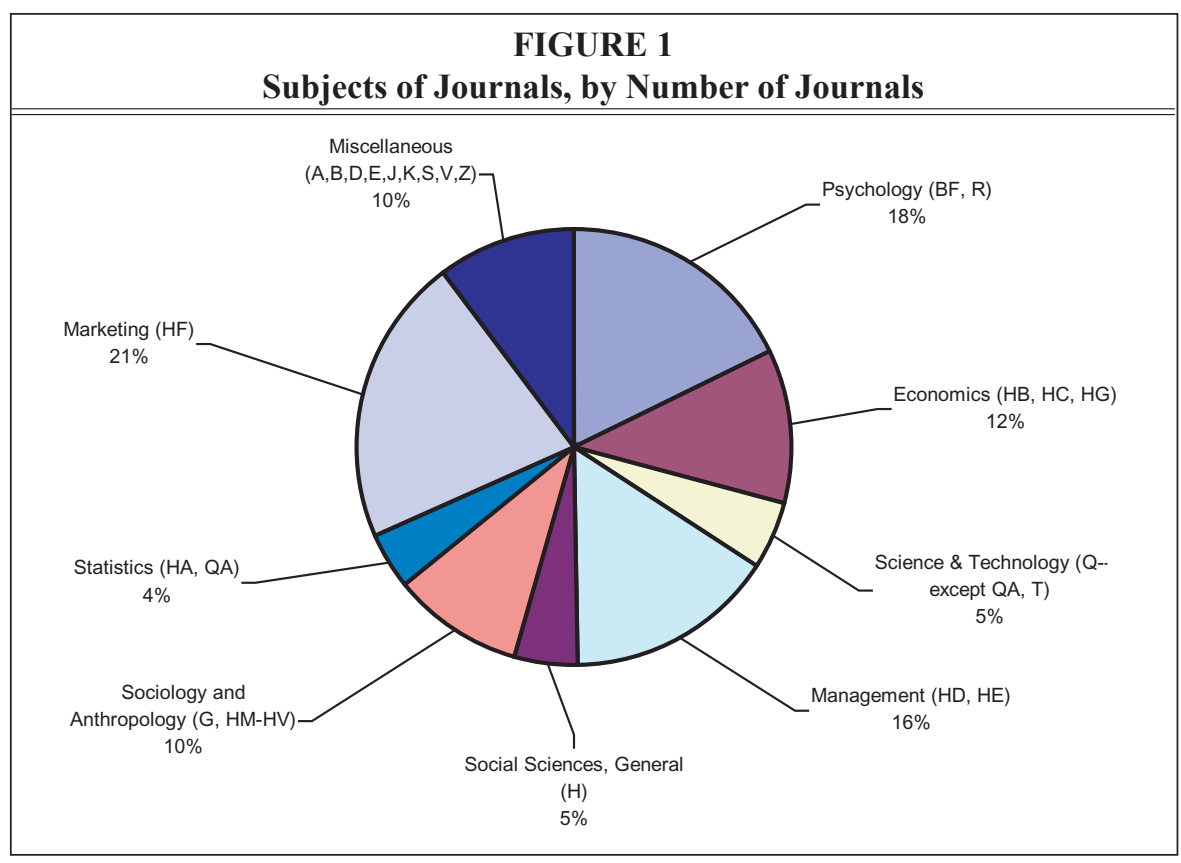




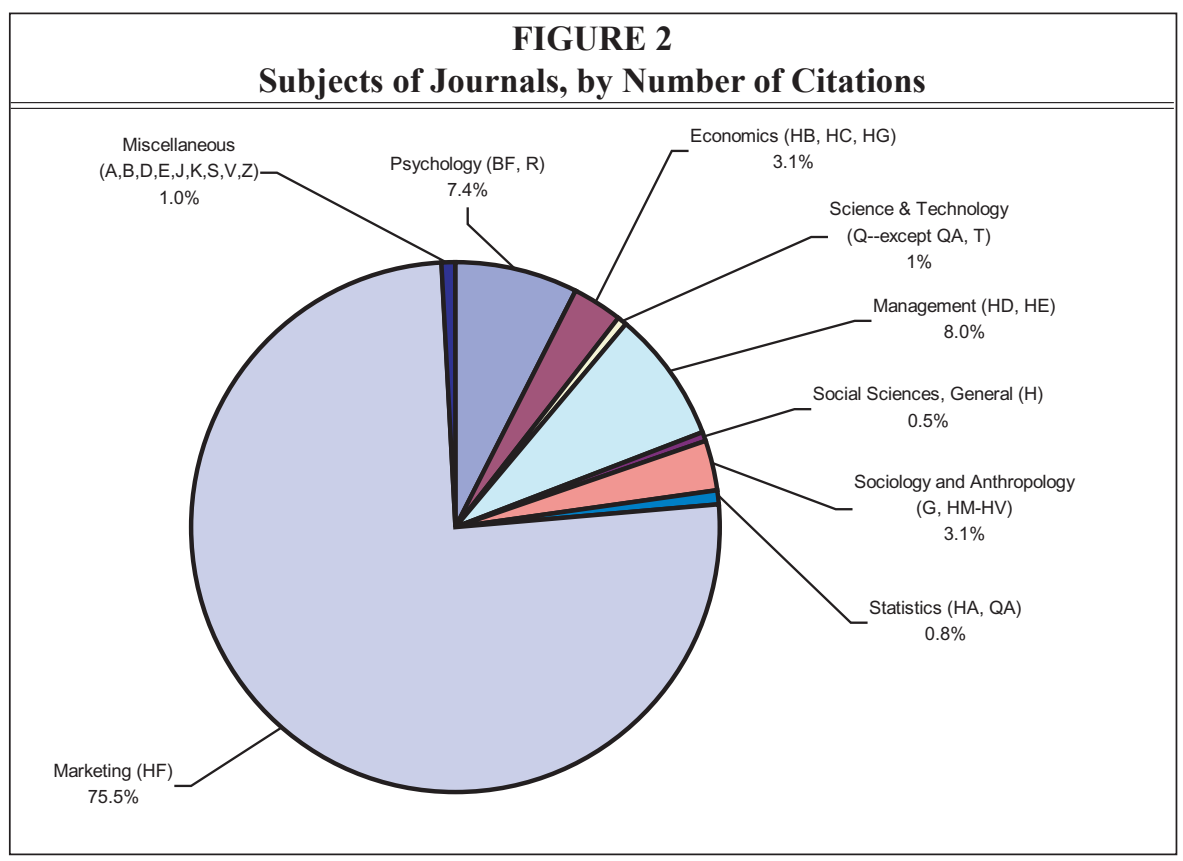

articles were cited thirteen times. But the twenty-eight most frequently cited articles represent only 5.0 percent of the total article citations. Over 82 percent $(5,173)$ of the articles appeared on the reading lists of five or fewer doctoral programs. Almost 35 percent of the articles $(2,188$, or $34.76 \%$ ) were cited in only one seminar. There is not a core list of seminal articles that compose the canon of the discipline's literature. (See table 3 for a distribution of the articles cited.)

Articles from special issues of journals were included on the reading lists more frequently than those from regular issues of the same journals. Most often, the journal editors or review boards invite notable researchers to submit articles for special issues. Their focus is frequently an underresearched or innovative topic. Apparently, these features of breaking new ground with articles from influential researchers make the issues more likely to be assigned and studied. For example, between 1991 and 2000, nearly 40 percent of the citations from the Journal of the Academy of Marketing Science came from three special issues published in 1992,
1999, and 2000. Articles from these special issues were cited nearly five times more frequently than articles from the regular issues during those years. Three other top marketing journals (Journal of Marketing, Journal of Marketing Research and Marketing Science) published special issues in the period 1991-2000. With the exception of the Journal of Marketing, articles cited in these special issues received higher citation rates than the other issues in those years. Special issues have a profound influence on the profession. They are likely to have higher use and longer shelf life than regular issues of the same journal.

\section{The Cited Books}

The 832 citations to books included 542 unique book titles. The same degree of scatter observed in the journal articles was shown among the cited books. One book, Thomas S. Robertson and Harold K. Kassarjian's Handbook of Consumer Behavior, was cited on nineteen of the reading lists, but the vast majority of the books (646, or $77.64 \%$ ) appeared on fewer than five lists. Four hundred twenty-eight books were found on only one list. This study 


\begin{tabular}{|c|c|c|c|c|}
\hline \multicolumn{5}{|c|}{ TABLE 3 } \\
\hline \hline $\begin{array}{c}\text { No. of } \\
\text { Articles }\end{array}$ & $\begin{array}{c}\text { No. of } \\
\text { Citations }\end{array}$ & $\begin{array}{c}\text { Citation } \\
\text { Total }\end{array}$ & $\begin{array}{c}\text { Percent of } \\
\text { Total }\end{array}$ & $\begin{array}{c}\text { Cumulative } \\
\text { Percentage }\end{array}$ \\
\hline 1 & 14 & 14 & 0.2 & 0.2 \\
\hline 2 & 13 & 26 & 0.4 & 0.6 \\
\hline 5 & 12 & 60 & 1.0 & 1.6 \\
\hline 15 & 11 & 165 & 2.6 & 3.9 \\
\hline 5 & 10 & 50 & 0.8 & 5.1 \\
\hline 17 & 9 & 153 & 2.4 & 7.6 \\
\hline 18 & 8 & 144 & 2.3 & 9.7 \\
\hline 29 & 7 & 203 & 3.2 & 12.9 \\
\hline 51 & 6 & 306 & 4.9 & 17.8 \\
\hline 72 & 5 & 360 & 5.7 & 23.5 \\
\hline 157 & 4 & 628 & 10.0 & 33.5 \\
\hline 271 & 3 & 813 & 12.9 & 46.4 \\
\hline 592 & 2 & 1,184 & 18.8 & 65.2 \\
\hline 2,188 & 1 & 2,188 & 34.8 & 100.0 \\
\hline Total= 3,423 unique articles & $\mathbf{6 , 2 9 4}$ article citations \\
\hline
\end{tabular}

demonstrates that doctoral students are exposed to a wide range of monographic literature, most of which cannot be successfully pigeonholed by either author or topic. The distribution of book citations is shown in table 4.

Works included on six or more seminars' reading lists are shown in table 5.

The subjects of the cited books also varied considerably. Predictablely, marketing call numbers (HF) dominated the field with 227 citations $(27.4 \%)$. However, other disciplines also were strongly represented: statistics (119), psychology (94), sociology/anthropology (92), research methodology in the social sciences (86), management (67),

\begin{tabular}{|c|c|c|c|c|}
\hline \multicolumn{5}{|c|}{ TABLE 4 } \\
\hline $\begin{array}{c}\text { No. of } \\
\text { Books }\end{array}$ & $\begin{array}{c}\text { No. of } \\
\text { Citations }\end{array}$ & $\begin{array}{c}\text { Citation } \\
\text { Total }\end{array}$ & $\begin{array}{c}\text { Percent } \\
\text { of Total }\end{array}$ & $\begin{array}{c}\text { Cumulative } \\
\text { Percentage }\end{array}$ \\
\hline 1 & 19 & 19 & 2.28 & 2.28 \\
\hline 1 & 16 & 16 & 1.92 & 4.20 \\
\hline 1 & 14 & 14 & 1.68 & 5.89 \\
\hline 1 & 13 & 13 & 1.56 & 7.45 \\
\hline 1 & 8 & 8 & 0.96 & 8.41 \\
\hline 4 & 7 & 28 & 3.37 & 11.78 \\
\hline 8 & 6 & 48 & 5.77 & 17.54 \\
\hline 8 & 5 & 40 & 4.81 & 22.35 \\
\hline 11 & 4 & 44 & 5.29 & 27.64 \\
\hline 18 & 3 & 54 & 6.49 & 34.13 \\
\hline 60 & 2 & 120 & 14.42 & 48.55 \\
\hline 428 & 1 & 428 & 51.44 & 100.00 \\
\hline Total = 542 unique titles & $\mathbf{8 3 2}$ book citations \\
\hline
\end{tabular}
science (52), economics (46), and philosophy (25). The topical range of the books cited illustrates the breadth of graduate marketing education and the variety of resources doctoral students read. (See figure 3.) This is in sharp contrast to the journal articles cited. As mentioned earlier, over 75 percent of the articles assigned were from journals classified as marketing, but only 27.4 percent of the books were. Libraries in universities offering these programs must understand that researchers in marketing require more monographic resources outside their

TABLE 4 
discipline than within their discipline by a ratio of more than three to one.

\section{The Age of the Resources}

Librarians should pay close attention to the publication year of sources listed as required or recommended readings. Decisions to acquire, retain, or store older issues of journals and books obviously hinge on anticipated usage. Although doctoral programs emphasize recent developments in theory, methodology, and empirical data analysis, it does not automatically follow that instructors and students rely solely on the latest research. To shed light on the currency of the cited sources, the researchers looked at the age of each citation. Age was defined as the difference between the year of use and the year of publication. Therefore, a citation that appeared on a reading list in the same year that it was published had an age of zero.

The median age of all the journal article citations was eight years; the mean was 10.3 years; the mode was one year. Professors obviously feel it is essential to expose doctoral students to the very latest literature, as 9.5 percent of all the articles read in the doctoral classes were no more than a year old. Over one-third of the cited articles were less than six years old and one half were published within eight years. Nonetheless, 10.2 percent were published before 1980. Despite the fact that professors weighted their reading lists with a heavy dose of current journal articles, older, probably seminal, articles have stood the test of time and continue to be part of the discipline's literature.

Citations from the five main marketing journals had a median age of seven years. The median age of citations from journals outside the five main marketing journals was ten years, indicating that many of these articles were probably more influential in a specific subdiscipline.

The average age for books was 16.52 years; the mean was twelve years; the mode was nine years. The most frequently occurring publication year was 1991. The earliest book cited was from
1934 (Institutional Economics, by John R. Commons). As with journal articles, very current works were heavily cited; 10.19 percent of the books had an age of zero or one. Although 46.5 percent of the cited books were published since 1990, sources published in the 1980s, 1970s, and even in the 1950s are still required reading in doctoral seminars.

The ages of all the sources with publication dates capable of being verified are shown in figure 4.

The broad age range of the required sources is a healthy reflection of the professors' efforts to maintain a cutting edge while, at the same time, building on the science's past.

\section{Conclusions}

Journal articles dominate marketing literature. Almost 87 percent of the readings assigned to doctoral students are journal articles whereas only 11.5 percent of the readings are from monographic sources. Professors customize the background readings they require by selecting and assigning specific articles to be studied. Textbooks or book-length collections of readings, if used, are heavily supplemented with specific journal articles tailored to the specialized approach of the professor or the theme of the course.

Although unstated, one must imply that marketing professors rely on their institutional libraries to provide convenient access to these articles in either printed or electronic formats. Although it is possible that some professors created course packs containing photocopies of the articles they assigned, none of the syllabi made mention of such a service. It must be assumed that institutional and departmental libraries, library reserve systems, and library-hosted databases are the primary suppliers of the seminars' assigned readings.

Librarians and scholars should continue to monitor the ratio of serial to monographic readings in marketing, as well as track the relative significance of popular magazines, newspapers, and Web sites. Changes in the type of litera- 


\begin{tabular}{|c|c|c|}
\hline \multicolumn{3}{|r|}{$\begin{array}{c}\text { TABLE } 5 \\
\text { Most Frequently Cited Books }\end{array}$} \\
\hline Rank & Citations & Book \\
\hline 1 & 19 & $\begin{array}{l}\text { Robertson, Thomas S., and Harold K. Kassarjian. Handbook of Con- } \\
\text { sumer Behavior. Englewood Cliffs, N.J.: Prentice-Hall, } 1991 .\end{array}$ \\
\hline 2 & 16 & $\begin{array}{l}\text { Lilien, Gary L., Philip Kotler, and K. Sridhar Moorthy. Marketing Mod- } \\
\text { els. Englewood Cliffs, N.J.: Prentice-Hall, } 1992 .\end{array}$ \\
\hline 3 & 14 & $\begin{array}{l}\text { Hunt, Shelby D. Modern Marketing Theory: Critical Issues in the } \\
\text { Philosophy of Marketing Science. Cincinnati, Ohio : South-Western Pub. } \\
\text { Co., } 1991 .\end{array}$ \\
\hline 4 & 13 & $\begin{array}{l}\text { Hair, Joseph F. Multivariate Data Analysis. Englewood Cliffs, N.J.: } \\
\text { Prentice-Hall [various editions]. }\end{array}$ \\
\hline 5 & 8 & $\begin{array}{l}\text { Bettman, James R. An Information Processing Theory of Consumer } \\
\text { Choice. Reading, Mass.: Addison-Wesley Pub. Co., } 1979 .\end{array}$ \\
\hline 5 & 8 & $\begin{array}{l}\text { Eliashberg, Jehoshua., and Gary L. Lilien. Handbooks in Operations } \\
\text { Research and Management Science. Volume 5: Marketing. New York: } \\
\text { North-Holland, 1990s. }\end{array}$ \\
\hline 5 & 8 & $\begin{array}{l}\text { Lindzey, Gardner, editor. Handbook of Social Psychology. Cambridge, } \\
\text { Mass.: Addison-Wesley 1954- [various editions]. }\end{array}$ \\
\hline 8 & 7 & $\begin{array}{l}\text { Berkowitz, Leonard. Advances in Experimental Social Psychology. New } \\
\text { York: Academic Press, 1964- [various editions]. }\end{array}$ \\
\hline 8 & 7 & $\begin{array}{l}\text { Cook, Thomas D., and Donald Thomas Campbell. Quasi-experimenta- } \\
\text { tion: Design and Analysis Issues for Field Settings. Boston: Houghton } \\
\text { Mifflin, } 1979 .\end{array}$ \\
\hline 8 & 7 & $\begin{array}{l}\text { Kuhn, Thomas S. Structure of Scientific Revolutions. Chicago: Univer- } \\
\text { sity of Chicago Press [various editions]. }\end{array}$ \\
\hline 8 & 7 & $\begin{array}{l}\text { Nunnally, Jum C. Psychometric Theory. New York: McGraw-Hill [vari- } \\
\text { ous editions]. }\end{array}$ \\
\hline 12 & 6 & $\begin{array}{l}\text { Bollen, Kenneth A. Structural Equations with Latent Variables. New } \\
\text { York: Wiley, } 1989 .\end{array}$ \\
\hline 12 & 6 & $\begin{array}{l}\text { Chalmers, A. F. What Is This Thing Called Science?: An Assessment of } \\
\text { the Nature and Status of Science and Its Methods. St. Lucia, Quebec: } \\
\text { University of Queensland Press [various editions]. }\end{array}$ \\
\hline 12 & 6 & $\begin{array}{l}\text { DeVellis, Robert F. Scale Development: Theory and Applications. New- } \\
\text { bury Park, Calif.: Sage, } 1991 .\end{array}$ \\
\hline 12 & 6 & $\begin{array}{l}\text { Eagley, Alice Hendrickson, and Shelly Chaiken. The Psychology of Atti- } \\
\text { tudes. Fort Worth, Texas: Harcourt Brace Jovanovich College Publish- } \\
\text { ers, } 1993 \text {. }\end{array}$ \\
\hline 12 & 6 & $\begin{array}{l}\text { Kerlinger, Fred N. Foundations of Behavioral Research. New York: } \\
\text { Holt, Rinehart and Winston [various editions]. }\end{array}$ \\
\hline 12 & 6 & $\begin{array}{l}\text { McGrath, Joseph Edward, Joanne Martin, and Richard A. Kulka. Judgment } \\
\text { Calls in Research. Beverly Hills, Calif.: Sage, } 1982 .\end{array}$ \\
\hline 12 & 6 & $\begin{array}{l}\text { Sheth, Jagdish N., David Morgan Gardner, and Dennis E. Garrett. Market- } \\
\text { ing Theory: Evolution and Evaluation. New York: Wiley, } 1988 .\end{array}$ \\
\hline 12 & 6 & $\begin{array}{l}\text { Zaltman, Gerald, Karen LeMasters, and Michael Heffring. Theory Con- } \\
\text { struction in Marketing: Some Thoughts on Thinking. New York: Wiley, } \\
1982 .\end{array}$ \\
\hline
\end{tabular}




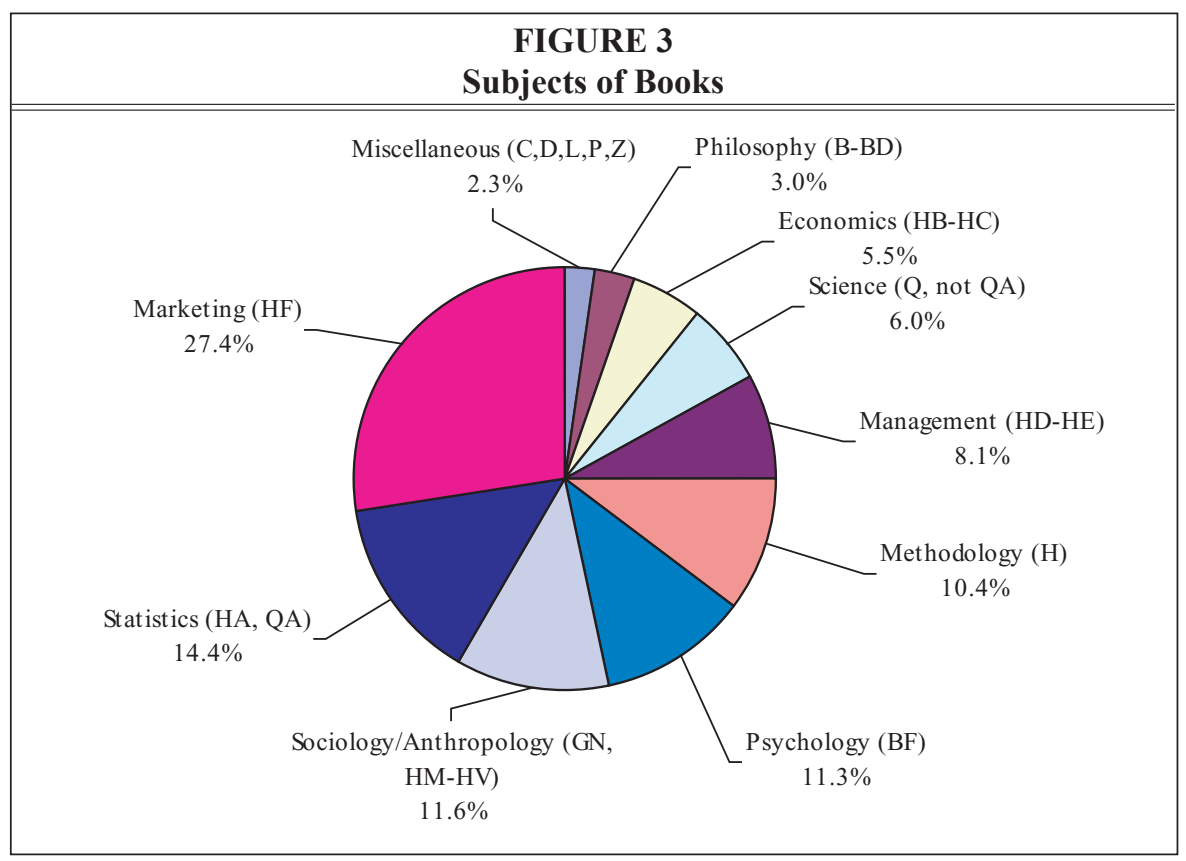

ture doctoral students read can have farreaching consequences for the profession and the libraries supplying the resources. It is worth remembering, for example, that after articles and books, drafts of professors' research reports comprise the next largest format listed on the syllabi.

Doctoral students are exposed to a body of knowledge primarily derived from a handful of journals. The present study confirms the preeminence of the Journal of Marketing as the principal vehicle for the distribution of influential articles in marketing. Consistent with earlier citation studies, this study also identified Journal of Marketing, Journal of Consumer Research, and Journal of Marketing Research as the foremost journals in the field.

The American Marketing Association (AMA) sponsors two of these flagship journals, Journal of Marketing and Journal of Marketing Research. Through these publications, the AMA has guided the discipline's development from a field that was largely descriptive to one with a strong scientific standing. The association has influenced virtually all levels of marketing research- ers and continues to influence current and future scholars. Because the AMA disseminates almost half of the journal articles read in doctoral programs, it must recognize the tremendous weight of responsibility it bears. AMA's editors must be careful to avoid unintentionally blocking diverse ideas or unestablished authors. Editorial decisions made by these premier journals not only determine what is published in the mainstream marketing outlets, but also determine the subject matter, the techniques, and the style of the resources that are used to educate doctoral students.

Respected core journals that report more practical research, such as Journal of Advertising, Journal of Advertising Research, Journal of Personal Selling and Sales Management, Journal of Retailing, and Journal of Pubic Policy and Marketing, are infrequently the source of assigned readings in doctoral marketing seminars. Although no marketing collection could be considered complete without these applied journals, marketing seminars obviously concentrate on a theoretical approach more commonly addressed in traditional academic sources. 


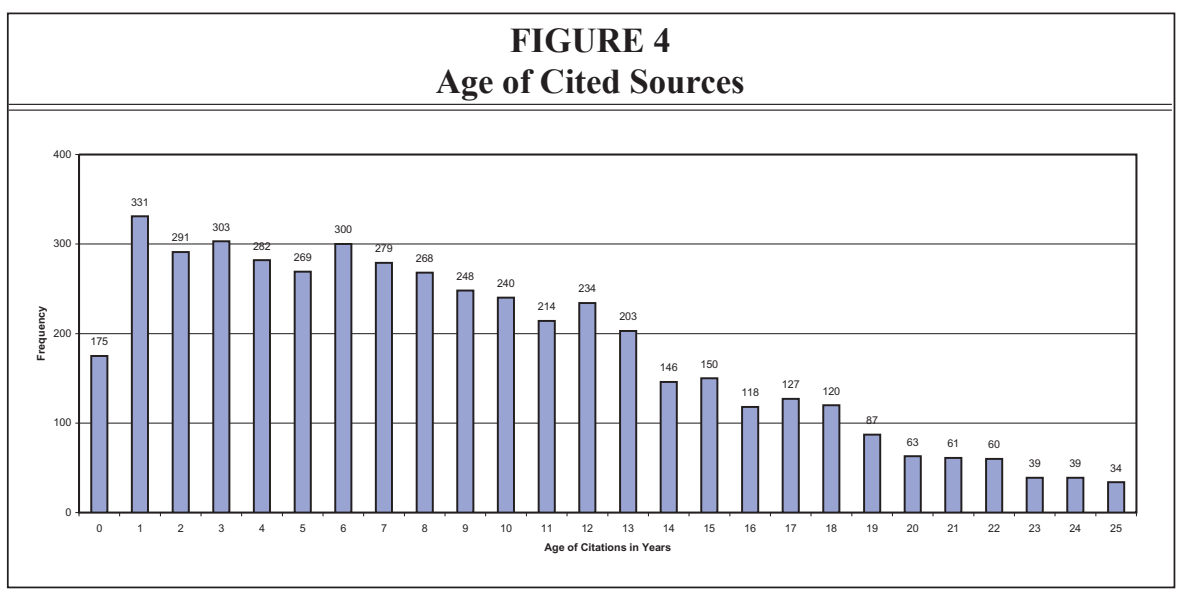

The syllabi identified a broad range of work from outside the marketing discipline, sources that earlier key informant and citation studies did not investigate. Psychology and management journals followed closely behind marketing journals as the sources for recommended readings. Although no individual nonmarketing journal exercised substantial influence, collectively, nonmarketing journals played a meaningful role. Libraries have an obligation to provide access to a broad range of business, statistical, and behavior-related journals to their marketing scholars. Departmental or college-based libraries will better serve their clientele by redefining their scope to incorporate sources beyond the literature based strictly on traditional marketing areas. Furthermore, administrators and librarians responsible for resource selection and de-selection decisions must understand that users of a discipline's resources are frequently from outside the commonly drawn confines of the discipline. All users of psychology journals, for example, are not psychologists.

Despite the high concentration of articles from the top marketing journals, the assigned articles were remarkably diverse. Even the most frequently cited article was mentioned by only 35 percent of the schools (14 of the 40 ). This lack of a common body of articles is evident even within the specific seminar topical areas, subdisciplines with a tighter focus and fewer core journals. Why is there such a scarcity of articles common across programs and within topical areas? Individual professors' approach, strategy, and overall philosophy significantly influence the articles selected. This diversity could signify that marketing is still a young science and that a common body of seminal resources will emerge only after the discipline matures. Nonetheless, marketing professors should question if greater standardization in readings is desirable. Certainly, increasing the number of sources universally assigned in seminars would enhance the common vocabulary among graduates of the programs and would have the potential to improve doctoral education.

Until that happens, however, there is little hope that a common textbook or collection of readings will satisfy the needs of all professors and students. Librarians will have to be vigilant in their efforts to study emerging trends in the discipline in order to anticipate and supply appropriate resources.

\section{Notes}

1. William G. Brown and Boris W. Becker, "Perceived Quality of Marketing Journals," Journal of Marketing Education 1 (Nov. 1979): 6-15. 
2. _Perceptions of Marketing Journals: Awareness and Quality Evaluations," in The 1985 AMA Educators' Proceedings, ed. Robert F. Lusch (Chicago: American Marketing Association, 1985), 149-54.

3. ㄴ. "Longitudinal Study of Marketing Journal Familiarity and Quality," in The 1991 AMA Educators' Proceedings: Enhancing Knowledge Development in Marketing, ed. Mary C. Gilly (Chicago: American Marketing Association, 1991), 702-10.

4. Gary L. Clark, "Leading Marketing Departments in the United States: Who Is Publishing Where and How Much Are They Publishing? in Proceedings of the AMA Summer Educators' Conference, ed. Terrence A. Shimp, et al. (Chicago: American Marketing Association, 1986), 149-53.

5. Robert K. Coe and Irwin Weinstock, "Evaluating Journal Publications of Marketing Professors: A Second Look," Journal of Marketing Education 5 (spring 1983): 37-42.

6. Elaine Hobbs Fry, C. Glenn Walters, and Lawrence E. Scheuermann, "Perceived Quality of Fifty Selected Journals: Academicians and Practitioners," Journal of the Academy of Marketing Science 13 (spring 1985): 352-61.

7. Peter J. Gordon and Kenneth A. Heischmidt, "Evaluation of Marketing Publications: Some New Findings," in Enhancing Knowledge Development in Marketing: 1992 AMA Educators' Proceedings, ed. Robert P. Leone and V. Kumar (Chicago: American Marketing Association, 1992), 318-19.

8. Robert H. Luke and E. Reed Doke, "Marketing Journal Hierarchies and Faculty Perceptions, 1986-1987," Journal of the Academy of Marketing Science 15, no. 1 (1987): 74-78.

9. Vasalis Theoharakis and Andrew Hirst, "Perceptual Differences of Marketing Journals: A Worldwide Perspective," Marketing Letters 13, no. 4 (2002): 389-402.

10. G. Tomas M. Hult, William T. Neese, and R. Edward Bashaw, "Faculty Perceptions of Marketing Journals," Journal of Marketing Education 19, no. 1 (1997): 37-52.

11. P. R. Chandy and Thomas G. E. Williams, "The Impact of Journals and Authors on International Business Research: A Citational Analysis of JIBS Articles," Journal of International Business Studies 25, no. 4 (1994): 715-28.

12. Joseph A. Cote, Siew Meng Leong, and Jane Cote, "Assessing the Influence of the Journal of Consumer Research: A Citation Analysis," Journal of Consumer Research 18, no. 3 (1991): 402-10.

13. Siew Meng Leong, "A Citation Analysis of the Journal of Consumer Research," Journal of Consumer Research 15 (Mar. 1989): 492-97.

14. Rich Pieters, Hans Baumgartner, et al., "Importance and Similarity in the Evolving Citation Network of the International Journal of Research in Marketing," International Journal of Research in Marketing 16, no. 2 (June 1999): 113-27.

15. George M. Zinkhan and Thomas W. Leigh, "Assessing the Quality Rankings of the Journal of Advertising, 1986-1997," Journal of Advertising 28, no. 2 (1999): 51-70.

16. George M. Zinkhan, Martin S. Roth, and Mary Jane Saxton, "Knowledge Development and Scientific Status in Consumer-Behavior Research: A Social Exchange Perspective," Journal of Consumer Research 19, no. 2 (Sept. 1992): 282-91.

17. Hans Baumgartner and Rik Pieters, "The Structural Influence of Marketing Journals: A Citation Analysis of the Discipline and Its Subareas over Time," Journal of Marketing 67, no. 2 (Apr. 2003): 123-39.

18. Frank R.Urbanic and J. Franklin Sailors, "Marketing Journals: A Study of University Library Holdings," Journal of Business E Finance Librarianship 2, no.2 (1997): 17-33.

19. Michael J. Polonsky, Gary Jones, and Megan J. Kearsley, "Accessibility, an Alternative Method of Ranking Marketing Journals," Journal of Marketing Education 21, no. 3 (1999): 181-93.

20. David L. Kurtz, Anne M. Velliquette, et al., "An Evaluation of the Marketing Theory Seminar in Ph.D. Programs: Teaching Alternatives and Future Directions," Marketing Education Review 7, no.2 (1997): 1-15.

21. Louis Capella and Ronald Taylor, "Marketing Theory Courses: A Longitudinal Analysis," in Proceedings of the 1989 Annual Meeting of the Southern Marketing Association, ed. Robert King (Charleston, S.C.: The Association, 1989), 242-46.

22. Charles J. Corrado and Stephen P. Ferris, "Journal Influence on the Design of Finance Doctoral Education," Journal of Finance 52, no. 5 (1997): 2091-2102.

23. Theoharakis and Hirst, "Perceptual Differences of Marketing Journals."

24. American Assembly of Collegiate Schools of Business, Doctoral Programs in Business $\mathcal{E}$ Management in the USA, 2001 (Victoria, B.C.: Academic, the El Group, 2000). 68.

25. "Schools of Business: The Top Schools," U.S. News \& World Report 130, no. 14 (Apr. 9, 2001):

26. Hult, Neese, and Bashaw, "Faculty Perceptions of Marketing Journals."

27. Baumgartner and Pieters, "The Structural Influence of Marketing." 